\title{
Virulence factors and drug resistance in Klebsiella pneumoniae; an emerging superbug
}

Faiza Liaqat $^{1}$, Wajeeha Naeem ${ }^{1}$, Muhammad Shafee ${ }^{2}$, Muhammad Anwar $^{3}$, Haleema Sadia ${ }^{4}$, Daud Ghilzai ${ }^{5}$ and Ali Akbar ${ }^{*}$

1. Department of Microbiology, University of Balochistan Quetta 87300, Balochistan-Pakistan

2. Center of Advance Studies in Vaccinology and Biotechnology (CASVAB) University of Balochistan Quetta 87300, Balochistan-Pakistan

3. Institute of Biochemistry, University of Balochistan Quetta 87300, Balochistan-Pakistan

4. Department of Biotechnology Balochistan University of Information Technology, Engineering and Management Sciences, Quetta Balochistan-Pakistan

5. Department of Gastroenterology Bolan Medical College Hospital Quetta Balochistan-Pakistan

*Corresponding author's email: aliakbar.uob@gmail.com

Citation

Faiza Liaqat, Wajeeha Naeem, Muhammad Shafee, Muhammad Anwar, Haleema Sadia, Daud Ghilzai and Ali Akbar. Virulence factors and drug resistance in Klebsiella pneumoniae; an emerging superbug. Pure and Applied Biology. Vol. 8, Issue 2, pp1314-1337. http://dx.doi.org/10.19045/bspab.2019.80074

\begin{tabular}{llll}
\hline \hline Received: 01/01/2019 & Revised: 29/03/2019 & Accepted: 10/04/2019 & Online First: 19/04/2019 \\
\hline \hline
\end{tabular}

\section{Abstract}

Klebsiella pneumoniae is a nosocomial pathogen usually concerned in hospital out- breaks with a propensity for antibiotic resistance (ABR) to support $\beta$-lactam antibiotics and several other antimicrobial classes. The effective feast, spread and infection of the Gram-negative bacterium can be credited to an innumerable of influences comprising host, environmental, virulence factors and a vast diversity of ABR mechanisms. The poor handling consequences and insufficient treatment options are significances of the effective pathogenesis and spread of ABR in the increasingly common in Klebsiella pneumoniae bacterium which producing $\beta$-lactamase. This is a comprehensive literature review on Klebsiella exploring all the drug resistance and pathogenicity related issues associated with this bug, it will provide a roadmap to the researcher for further research extension in this field.

Keywords: Antibiotics; Public health; Pathogenicity; Superbugs; Virulence factor

Introduction

Klebsiella genus belongs to

Enterobacteriaceae family, frequently rod in shape, grams negative, expanded, lysine decarboxylase but not ornithine decarboxylase producers, and commonly positive in the Voges-Proskauer test [1]. These bacteria are permeating in the environment, and is commonly perceived a diversity of ecological sorts including soil, aquatic, vegetation and sewage due to colonization in nasopharynx and gastrointestinal tract it can act as an opportunistic pathogen in human [2]. It has also been seeming in insects [3] and various mammals.

Clinical importance spp. of Klebsiella is Klebsiella pneumoniae which is the maximum significant pathogen in Klebsiella genus, existence responsible for $86 \%$ of 
infections. Moreover, Klebsiella oxytoca is the second most prevalent Klebsiella spp. and it's responsible for $26 \%$ of infections [4]. Klebsiella are known as important pathogenic agents in nosocomial infections, which causes several infections in urinary tract and affect the wound, soft tissues and causes septicemia [1].

Klebsiella spp. infections may predispose to several host characteristics such as, cardiac diabetes, or pulmonary chronic diseases, extremes of age, renal, as well as oncologic problems [5, 6]. Colonization rates of Klebsiella spp. in the hospital environment rise and related to antibiotic therapy. The nature and numeral of virulence factors causing the alterations in medical feature of infections. It has the possibility to causing many infection in urinary, blood, respiratory and wound and liver abscess syndrome reported recently in Asian countries [7]. A plasmid- borne gene (rmpA) and K1-specific gene (magA) are subsequent high virulence strains that is related with hypermucoviscosity (HMV) phenotype [8]. The infection of Klebsiella pneumoniae is impaired by its high probable of dispersal in the care units and it can acquire multidrug resistance (MDR). The initiation of Klebsiella pneumoniae with plasmidencoded extended spectrum of beta lactamase (ESBL) action is subsequent in significant illness and death, due to handling failure and consequent septicemia [9].

\section{Virulence factors and gene}

There are several virulence factors that have been related to the pathogenesis of Klebsiella Klebsiella spp. has the capability to use allantoin as a font of N2 [13]. All S gene that is present at the $22 \mathrm{~kb}$ region of Klebsiella pneumoniae has been linked to liver infection. Additionally, intra gastric infection in the strain of wild type show a virulence as linked to mutant. Another recognized factor is urease which is responsible for pathogens; it causes an extensive sort of pathologies spp. infections. Additionally, capsule and adhesins, HMV, quisition system, serum resistance, biofilm formation is common among them [2]. In Klebsiella spp. the important factors for virulence are adhesions like type 1 and 3 fimbriae that give the development of respiratory and urinary tract infection (UTI). Type 1 fim has a role in UTI that's report in Klebsiella pneumoniae [10]. In addition, type 1 pili is too contributing to form some colonies of respiratory tract and urogenital and it's not contribute only UTI but also for development of pneumonia [2]. Presence of rmpA gene has been related through the phenotype HMV in Klebsiella pneumoniae, and it was found more widespread in liver abscess strains as compared in bacteremia isolates. This gene is more commonly perceived between strains from $\mathrm{K} 1 / \mathrm{K} 2$ serotypes. Therefore, it is suggesting that this gene might be an indicator of Klebsiella pathogenicity islands which is directly related to virulence [11]. Genes encoding virulence in adhesions (fimH-1, mrkD, kpn, ycfM) among them capsule factor is more virulence because it protects the bacterial cells from phagocytosis and against serum killing [1]. It is found that capsule is factor in numerous animal infection serogroup $\mathrm{K} 1$ and 2 were to be mostly lethal in mouse peritonitis model as it is related to another capsular antigen. A skin lesion in mice that was experimentally induce $\mathrm{K} 1$ to K5 capsular antigen found more virulent than other antigens [12].

including peptic ulcers, pyelonephritis and urolithiasis [14]. ureA mutant in Klebsiella pneumoniae have a weekend ability to colonize [15]. ureA mutants in Klebsiella pneumoniae have an attenuated the mouse intestine. The nosocomial infection that is produced by Klebsiella pneumonia, are usually led by gastrointestinal colonization although of the infection localization, so this 
ability to increasing colonization in that tract make a urease as a factor for virulence [15]. Siderophore are highly affinity extra cellular ferric cheletor which are secreted by bacterial cells they have a serious role in microbial virulence. Klebsiella ferric iron uptake (kfu) is a virulence factor responsible for iron uptake this factor allows Klebsiella to get iron if there is limited iron condition is avaible through the human host [16]. Virulence gene encoded siderophores are (entB, iutA, irp-1, irp-2, ybtS, and fyuA) [1].

2. Antibiotic-resistance mechanisms in Klebsiella pneumoniae

Inborn antimicrobials predisposition could be impacted by adaptive responses, causing variations in gene expression and functioning of cell, which remain influenced in reaction to the pathogen's natural ecological pressures on host $[17,18,19]$. The ABR mechanisms which are existing in Klebsiella pneumonia, include (1) modification of drug or enzymatic inactivation (2) Antibiotics (AB) mark modification or reduced amount of $A B$ inside cells and (3) greater activity of efflux [20, 21]. These are determined either inherently or learned over mutation and resistance gene attainment [17, 21].

Antimicrobials not only responsible for adaptive responses but it's also due to environmental pressure that contain: (i) end of growth, (ii) resistance determinants attainment which produce stress, (iii) Altered target sites (iv) Change the roles of membrane barrier, (v) stimulation of resistance-conferring mutations [17, 20]. Atypically, some defensive reactions triggered an importance to begin stress by $\mathrm{AB}$ can cause resistance to a very similar antimicrobial drug $[18,19]$. Modifications in membrane absorptivity and flux of $\mathrm{AB}$ can be predisposed by inconstant appearance and regulation of the efflux pump [20]. An important bacterial efflux pump family is the resistance nodulation division (RND) $[22,21$, 23]. The active appearance of the chromosomal native AcrAB-TolC efflux pump of the RND family gives to fluoroquinolones resistance in Klebsiella spp. E. coli and Enterobacter spp. [22, 23, 24]. Alternately, the change in protein of outer membrane of both Klebsiella pneumoniae and $E$. coli, owed to mutations or porins deletion, may bound influx of $\mathrm{AB}$ agents or consecutively rise efflux [21]. Moreover, the main OmpK 35 and 36 porins, the other OmpK 37 porins can be uttered by Klebsiella pneumonia.

The role of these porins in ABR not studied carefully then is assumed to be significant in the absence of OmpK 35 and 36 [25]. Modification or destruction of the OmpK 35 to 36 porin proteins can distress resistance in numerous conducts also important to raised (MICs) or resistance to carbapenem and extended spectrum cephalosporins, reduced fluoroquinolones exposure, or it might infrequently consult extra cross-resistance to quinolone, aminoglycosides and cotrimoxazole within broad-spectrum beta lactamase or ESBL-producers [26, 27, 18, 19].

A further alteration to the outer membrane assisting in resistance, other than porin loss, is the up ruling of capsule polysaccharide production in Klebsiella pneumoniae [22, 28]. Bacteriological cells can occur as particular cells, the planktonic form, or in societies worn together by an own made bio polymer medium and devoted to an external $[29,19,30,31]$. Genetic elements consulting latent resistance genes are simply conveyed parallel both inter and intra classes owed to the near genetic similarity among bacteria of the Enterobacteriaceae family [17, 20].

The reduced $A B$ drug effect in contrast to bacterial residents in a biofilm is mostly indistinct but might be as a consequence of numerous mechanisms acting in conjunction, such as: (i) poor compound diffusion, (ii) the gentler development and uptake of $\mathrm{AB}$ by the bacteria in settled biofilm ( $>24$ hours old), 
(iii) the making of $\mathrm{AB}$ disabling enzymes, (iv) broad strain reactions, (v) appearance of efflux pump (vi) existence of persisted cells $[17,29,19,30,31,32]$. Formation of biofilm in Klebsiella pneumoniae is inclined by cell concentration reliant on minimum recognizing gesturing by the non-specific bacterial type-2 QS controlling molecules, AI-2 auto inducers [33]. Mannose-resistant Klebsiella-like $(\mathrm{MR} / \mathrm{K})$ haemagglutinin are determined in mrk gene ABCDF in an operon and procedure extent fimbriae 3 type that is significant to arbitrating biofilm formation in Klebsiella pneumoniae [34]. ABR can rise to 1000 -fold for bacterial cells present in the biofilm [30, 35].

Further reasons on show too ESBL making comprise hyper production of cases of ESBL cases owed to organizer active regulation subsequently through mutation, implanted transposable components in nearby nearness toward the organizer and the capacity to this coproduce additional than one ESBL [27] (Figure 1 \& Table 1).

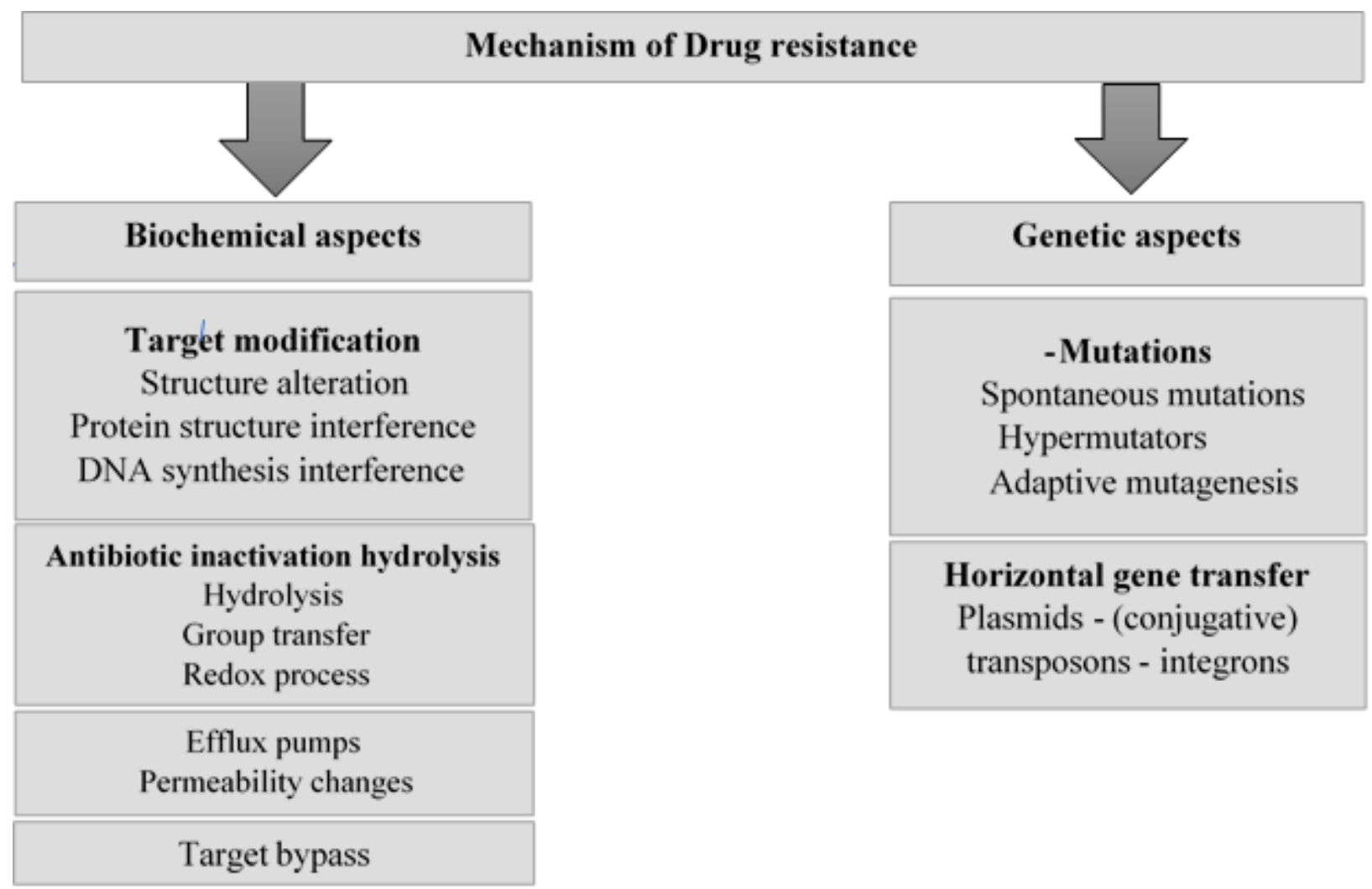

Figure 1. Common mechanism of durg resitance in Klebsiella spp.

Enzyme mediated resistance to $\beta$-lactam AB was revealed firstly in $E$. coli then has later feast to a huge numeral species of bacteria in the form of concluded 890 inimitable $\beta$ lactam [36]. Moreover Bush-JacobyMedeiros efficient groups established on hydrolysis and reserve appearances or protein constructed 4 classes of Ambler molecular, bush-jacoby-medeiros categorized the $\beta$ - lactam into 3 groups and sixteen subclasses $[22,36-38]$. Few of these gene which have resistance, achieved over many genetic but portable components, which include transposons, insertion sequence elements and plasmids [39, 40].

\subsection{B-lactam resistance genes}

Since the 1940s $\beta$-lactam antibiotics, was used clinically which are a main 
antimicrobial agent class suggested in humanoid treatment. According to Bush and Jacoby [41]. There are dissimilar $\beta$-lactam which have developed between enteric pathogens containing Klebsiella pneumoniae, attainment a surprising amount at about (>2000) and diversity [42]. According to Sirot et al. the initial ESBL gene was describe are those gene which show an extended spectrum action against $\beta$-lactam (third-generation cephalosporins and monobactams) in France the modified gene blaTEM-3 plasmid-mediated ESBL was reported. During the 1990-2000s, Klebsiella pneumoniae has come to be the most important ESBL-carrying pathogen related in nosocomial outbreaks. During the 1990 2000s, Klebsiella pneumoniae has come to know the major nosocomial outbreak that have ESBL-carrying pathogen. 40\% ESBL production were found in hospital isolate [43, 44]. Klebsiella pneumoniae strains frequently TEM and SHV $\beta$-lactamases were hid in that period [45]. Resistance to betalactam antibiotics is acquired due to the presence of beta-lactamase gene [162]. Hospital outbreaks producing Klebsiella pneumoniae that have an alteration in ESBLs present in them it was due to attainment of plasmids and transposons encoding that causes dominance in strain that producing CTX-M [46]. blaOXA gene a -type of ESBLs were shifted to Klebsiella pneumoniae by horizontal gene transfer [47], and other blaGES in addition blaSFO [48] or blaPER, blaTLA and blaVEB [49]. Furthermore, some gene producing enzymes that subdued by acid tazobactam and clavulanic that gene are inhibitor-resistant $\beta$-lactamase [36] WHO [50] reported in different geographical regions the ESBL gene content and prevalence varies and in different part of world the endemic rates of the incidence of Klebsiella pneumoniae that producing ESBL- has got resistance up to $49 \%$ and $30 \%$ rates of the widespread nature in the public representative.

\subsection{Plasmid-mediated AmpC genes}

The notable adaptability of Klebsiella pneumoniae to include $\beta$-lactam genes onto movable plasmids that permit their feast, provided rise to the appearance and spread of plasmid mediated AmpC-like cephalosporins in this classes $[51,36]$. These genes arisen in the 1990s, in equivalent with the explosion of ESBL genes, and they are entirely plasmidborne in Klebsiella pneumonia. The furthermost abundant blaAmpC gene families in this classes belong to the CMY, DHA, FOX and MOX types, and their Klebsiella pneumoniae strains presentation developed resistance to $\beta$-lactam owing to the existence of blaAmpC shared over porin harm, or more efflux, were too described as through the case of blaACT-1. Due to several copies these all genes can expressed on plasmids, or enlarged administrative quality of plasmid genes, and uniform lead to carbapenem resistance [51].

\subsection{Carbapenem resistome}

The widespread incidence of ESBLproducing Klebsiella pneumoniae in diverse portions of the world was exposed that novel type of ESBL and alleles confined via this species, and in other Enterobacteriaceae, assimilated by transfer of plasmids and transposons that encoding ESBLhorizontally. The Klebsiella pneumoniae strains that producing ESBL have phenotypic characteristics of MDR run to a main rise in carbapenem use, which became the latter alternative $\mathrm{AB}$ to treat Klebsiella pneumonia that producing ESBL [52]. The wide practice of carbapenem has caused in the development of plasmid-mediated carbapenemases, all beta lactamase comprising the last-line carbapenem had hydrolyzed by these enzymes [53]. Their presence in enterobacteriaceae run to carbapenem-resistant enterobacteriaceae. In all probability Owed to their sickbay 
association of Klebsiella spp. Its consider to be major enterobacteriaceae that have to extent global, causing a major community healthiness risk [54], back in 1983 the initial carbapenem $\mathrm{AB}$ imipenem was the used to treat infections that cause by Klebsiella pneumoniae, and after 2 years the strain that resistant to imipenem were identified. In 1991 in japan the earliest detected carbapenem was imipenem-1 metalloenzyme [55], in 1996, another carbapenem in Klebsiella pneumoniae, was arisen in the United States informed which called KPC [56]. While other carbapenem genes blaOXA-48 arisen in Klebsiella pneumonia and were even reported [57], and blaNDM-1 [58], blaKPC gene in carbapenem Klebsiella pneumoniae developed the most extensive and vastly impacting. In many countries, the hospital outbreak was mostly prevalent in those strains that exist with these two gene blaKPC-2 and blaKPC-3 [59]. Since it was initially reported in us that the chief powerful force for range of these was and is immobile clonal extension of Klebsiella pneumoniae ST258 [60].

Has develop widespread in worldwide [61]. blaKPC genes exist in an exclusive Tn4401 transposon $\mathrm{T}$ alternatives among by clonal spreading [62] and are implanted into plasmids of several sorts of replicon, which helps the spreading of the gene to another species of bacterial [63]. In US, it was reported that an exciting instance of interspecies transfer blaKPC-3 gene of transposons-encoded from Klebsiella pneumonia to E. coli was. E. coli plasmid hiding in isolate of serratia marcescens and this transposon was successively improved from the patients, representative Klebsiella pneumoniae as an origin for KPC genes in numerous pathogens [64]. Along by their action in contradiction of all $\beta$-lactam $A B$ and high transmission capacity, KPCs frequently keep resistance to communal $\beta$-lactamase inhibitors, posturing a medical contest [65].
Raised death was revealed for infections that is formed by Klebsiella pneumoniae that is producing KPC [61]. Through the rising repetition of carbapenem to treat Klebsiella pneumonia that making ESBL and origins infections, frequent developments arisen: (i) carbapenem resistance appeared lacking the real bearing of a carbapenem gene as a significance of penetrability variations owed to loss of porin and over appearance of efflux pump. The initial report of this phenomenon was in 1988 [66], and was more established by a mixture of high-level plasmd mediated AmpC blaACT-1 organized through loss of porin; reduced vulnerability to ertapenem by a combination of ESBL and harm of OmpK36 [67], and the influence of AcrAB efflux pump [68]. (ii) The appearance of single ESBL genes by broader range of activity, such as blaGES [53]. The blaGES-4 in Klebsiella pneumoniae was recognized in 2002 which was initial GEStype [69].

\subsection{Multiple $\quad \beta$-lactamase-encoding Klebsiella pneumonia}

In the identical strain the carriage of multiple $\beta$-lactamase genes is a recognized capability of Klebsiella pneumoniae and it may give rise of this pathogen. All classes of bla genes were stated in this species [70]. It's might possibly be to at all (i) carriage of an ABR plasmid encoding an range of antibiotic resistance genes owed to acquisition of transposons comprising diverse bla genes which is present on the same plasmid or (ii) co-carriage of more than one antibiotic resistance plasmid. Distinct strains might transmit many genes of bla similar the report of a strain in NY City which were secluded from a mucus of a hospitalized persistent, carrying at nearby 10 different genes of bla with a FOX-like plasmid mediated, AmpC, blaKPC, blaSHV and inhibitor resistant $\beta$ lactamase [71], according to Doi et al., [72] another strain containing blaNDM-1 and OXA-232 having 2 variant plasmid on it. The 
evolutionary benefit for Klebsiella pneumoniae to haven multiple $\beta$-lactamase through an overlying catalytic activity is an understudied range. Around are signals that variety of $\beta$-lactam might be involved in additional consistent resistance. For example, imipenem, carbapenemase are susceptible first to aztreonam between $\beta$-lactam $\mathrm{AB}$, but they frequently hide that slit through the occurrence of ESBL or AmpC $\beta$-lactamase [73]. Additional duplicates of genes were too associated to develop resistance level, microbial response to enlarged $\mathrm{AB}$ amount [74].

\subsection{Aminoglycoside resistance genes}

Aminoglycosides were vigorously used since mid-1940s to $1980 \mathrm{~s}$ until they were exchanged with 3rd-generation, cephalosporins, fluoroquinolone and carbapenem [75]. In this era of practice, they get increase level of resistance mechanisms contrary to this drug, due to occurrence of drug alteration in enzymes taking diverse actions. Less usage of aminoglycosides usage reduced the evolution of novel phenomena of resistance active to the finding of $16 \mathrm{~S}$ rRNA methylase, which relating to the family of armA gene it contains an enzyme which avoid aminoglycosides to joining with their 16S rRNA target [76]. In Klebsiella pneumoniae the plasmid is encoded by these genes [77], and although drug altering enzymes have a fine range of action, $16 \mathrm{~S}$ rRNA methylase consult resistance to almost wholly aminoglycosides, with plazomicin, the furthermost current aminoglycosides composite established [78].

In Klebsiella pneumoniae armA gene location on Chromosomal was defined single after [79]. Further recognized plasmid mediated 16S rRNA mt with Rmt family and NpmA were too initiate in Klebsiella pneumoniae [75], through no signal of chromosomal position. Resistance phenomena of Chromosomal in contrast to aminoglycosides in Klebsiella pneumoniae contain alterations in cell penetrability owed to changes in AcrAB-TolC and KpnEF efflux pump systems, and due to damage of assumed porin, KpnO. Troubles in AcrABTolC improved vulnerability to tobramycin and gentamicin [68], while kpnEF mutant displayed strong alteration in resistance to tobramycin and spectinomycin, then pretentious only somewhat resistances to gentamicin and streptomycin [80] but affected only a little resistance to gentamicin and streptomycin. This might recommend changed considerations of the penetrability apparatus to changed aminoglycosides. Through contribution in aminoglycosides resistance was defined in vitro for $\mathrm{KpnO}$ porin, which upon harm produced resistances to tobramycin, streptomycin and spectinomycin. Alterations which converse resistance through mark change, like rrs or rpsL which has not present in medical strains of Klebsiella pneumoniae. It is probable that rpsL alterations are associated through high capability rate and compact virulence, thus they are fewer choice. Several duplicates of rrs in chromosome of Klebsiella pneumoniae might too confound the resistance to be rise owed to transformations in this gene [81, 82].

\subsection{Quinolone resistance genes}

Quinolone target bacterial topoisomerases obstructive bacterial DNA repetition. It's used in therapeutic field subsequently the 1960s, then their usage improved widely after the overview of the chief fluoroquinolones in the 1980s, which has directed to progress of bacterial quinolone resistance phenomena [83]. Klebsiella pneumoniae resistome associations wholly the resistance mechanisms recognized for resistance of quinolone in gram negative bacteria [84], with mark location gene mutations, rise manufacture of MDR efflux pump, altering enzymes or mark defense proteins. Cases of Klebsiella treated with nalidixic acid, the initial clinically accepted quinolone [85], and 
first fluoroquinolones used by Klebsiella pneumoniae was norfloxacin, the [86].

\subsection{Tigecycline resistance genes}

Tigecycline is the initial glycylcycline flung, and this drug has been practicing contrary to Klebsiella pneumoniae infections till 2005, afterward it was revealed to escape after the chief resistance mechanisms recognized against tigecycline [87]. It was a probable drug that show an activity of broad-spectrum against those isolate which producing ESBL [88]. Presently when its use primary, an MDR Klebsiella pneumonia strain owning reduced tigecycline vulnerability (MIC 4 $\mu \mathrm{g} / \mathrm{mL}$ ) was secluded at a hospice [89]. Conferring to the presently suggested tigecycline divides, this strain was intermediately resistant to tigecycline [90] though it was report, that in Klebsiella pneumoniae isolates tigecycline resistance has been increased.

\subsection{Tetracycline resistance genes}

Tetracycline (TET) has been commonly used for the management of infections, but inappropriately frequent use of this drug has caused in the progress of resistant in most strains. TET resistance in bacteria is arbitrated through 4 mechanisms: enzymatic inactivation, efflux, ribosomal protection, and target modification [91]. It was reported that about genes encoding for efflux pump were 23 , not containing the newly defined mosaic TET resistance genes reported [92]. In preceding surveys of clinical, tetB gene was recognized as the greatest widespread TET resistance cause with an extensive host sort since it exists in on extremely transportable hereditary components that freely allocation among unlike genera of bacterial. The gene tetA is found on conjugative plasmids of altered unsuitability groups [93].

Table 1. Drug resistance genes and mechanisms for selected antibiotics

\begin{tabular}{|c|c|c|c|}
\hline Antimicrobial & Genes conferring resistance & Mechanisum of resistance & References \\
\hline Aminoglycosides & $\begin{array}{l}\text { acrB, kpnEF, } \\
\text { rpst, armA, } \\
\text { KpnO }\end{array}$ & $\begin{array}{l}\text { Efflux pump, } \\
\text { Modification of drug, } \\
\text { Porin loss }\end{array}$ & {$[80]$} \\
\hline$\beta$-lactams & $\begin{array}{c}\text { AcrAB/ToiC, KpnEX, AcrB, } \\
\text { PhoE, } \\
\text { SHV-1, SHV-49, } \\
\text { cpxAR, acrR,ramA, } \\
\text { OXA-181, NDM-1, VIM,KPC-3, } \\
\text { CMY-2, CTX-M-15 }\end{array}$ & $\begin{array}{c}\text { Efflux pump, } \\
\text { Porin loss, } \\
\text { Penicilinases, } \\
\text { Pump/porin regulator, } \\
\text { Carbapenemases, } \\
\text { AmpC, ESBL } \\
\end{array}$ & [47] \\
\hline Quinolones & $\begin{array}{c}\text { KdeA, acrAB, oqxAB, } \\
\text { PaeE, gyrA, gyrB, parC, } \\
\operatorname{rarA} \text {, oqxR, soxS, marA, ramA, acrAB }\end{array}$ & $\begin{array}{c}\text { Efflux pump, } \\
\text { Modification of drug, } \\
\text { Pump/porin regulator }\end{array}$ & {$[83]$} \\
\hline Polymyxins & $\begin{array}{l}\text { crrAB, pmrC, pagP, pmrE, pbgP, lpxM, } \\
\text { cps, rarA, ramA, mrgB, rarA, rcsB, rcsC, } \\
\text { rcsD, phoPQ, pmrAB, pmrD }\end{array}$ & $\begin{array}{c}\text { Modification of drug } \\
\text { Pump/porin regulator } \\
\text { Regulatory of modifing } \\
\text { enzymes } \\
\end{array}$ & [83] \\
\hline Tigecycline & $\begin{array}{l}\operatorname{kpg} \mathrm{ABC}, \text { oqxA, acrA } \\
\text { rpsJ rarA, ramR, acrR, ramR }\end{array}$ & $\begin{array}{c}\text { Efflux pump } \\
\text { Modification of drug } \\
\text { Pump/porin regulator }\end{array}$ & [89] \\
\hline Tetracycline & tet $\mathrm{A}$, tetB & Modification of drug & [93] \\
\hline
\end{tabular}

\subsection{Extensively drug-resistant XDR resistome}

The rise of several resistances to changed $\mathrm{AB}$ groups is commonly originate in hospitaladapted Klebsiella pneumoniae isolates owed to the growth of ranges of antibiotic resistance genes that determined on numerous plasmids establishing a 'super resistome'. A great resistome might include groupings of ESBLs and/or carbapenem 
genes with AmG altering enzymes, or suggestion of CTX-Ms or NDM carbapenem with $16 \mathrm{~S}$ rRNA $\mathrm{M}$ as defined in an existing investigation [75]. IncA/C plasmids, for instance, encode carbapenem composed through $\mathrm{rmt} \mathrm{M}$, quinolone resistance gene qnrA and AmpC- $\beta-\mathrm{L}$ blaCMY [94]. Additional exciting case of a Klebsiella pneumoniae strain owning a super resistome was exposed carrying 4 changed $\beta$-lactam (blaNDM-1, blaCMY-16, qnrA and armA on one plasmid and blaOXA-48 and 15, individually on distinct plasmids), organized by porin absence, additional antibiotic resistance genes and chromosomal mutations in quinolone resistance [95].

3. Klebsiella pneumoniae-resistance to third-generation cephalosporin and to carbapenem

A comprehensive date from published literature has been presented in (Table 2 \& 3) regarding the resistance in Klebsiella pneumoniae to cephalosporin (CSN), which have been the typical intravenous management for uncomplicated infection of Klebsiella in hospitals, and to carbapenem, which are the last choice for handling of plain infections when CSN are no prolonged dependable due to a great volume of ESBLmediated resistance. Data shows that resistance proportions to $3^{\text {rd }}$ generation of CSN were frequently developed in Klebsiella pneumoniae. The high extents of CSN resistance revenue that handling for complete or assumed severe Klebsiella pneumoniae infections in various conditions must rest on carbapenem, uncertainty obtainable. This generally includes developed charges and a hazard of more development of carbapenemresistant strains. Of level, larger concern is that infections with carbapenem-resistant strains essential to be treated through the lastresort drugs tigecycline or colistin, which are not only a reduced amount of effective then too not widely existing. Thirty studies were involved for $3^{\text {rd }}$ generation CSN-resistant Klebsiella pneumoniae, and 13 for carbapenem resistant Klebsiella pneumoniae.

Table 2. Klebsiella pneumoniae: Sleeted literature on resistance to $3^{\text {rd }}$ generation Cephalosporin

\begin{tabular}{|c|c|c|c|c|}
\hline Countries & Resistance \% & Isolates & Samples type & References \\
\hline $\begin{array}{c}\text { Bosnia and } \\
\text { Herzegovina }\end{array}$ & $\begin{array}{c}50(\mathrm{CTX}) ; 60(\mathrm{CRO}) ; \\
61.5(\mathrm{CAZ})\end{array}$ & & Gynecology & {$[126]$} \\
\hline Trinidad and Tobago & 15,2 & 403 & Clinical isolates & [127] \\
\hline Brazil & 55.6 & 81 & Blood stool & {$[128]$} \\
\hline Mexico & 37 (CRO); 38 (CAZ) & 150 & Clinical isolates & [129] \\
\hline Iraq & 32.3 & 31 & UTI (OP) & [130] \\
\hline Iraq & $\begin{array}{l}17 \text { (CTX) } \\
43 \text { (CAZ) } \\
50 \text { (CRO) }\end{array}$ & 30 & BI (ICU) & [131] \\
\hline Kuwait & $\begin{array}{l}20 \text { (com) } \\
33 \text { (hosp) }\end{array}$ & $\begin{array}{l}253 \text { (com) } \\
217 \text { (hosp) }\end{array}$ & $\begin{array}{c}\text { Urinary infections; } \\
\text { (Com \& Hosp. acquired) }\end{array}$ & [132] \\
\hline Lebanon & 29 (CTX), 21 (CAZ) & 947 & Hospital samples & [133] \\
\hline Morocco & $\begin{array}{l}69.5(\mathrm{CAZ}) \\
75(\mathrm{CRO})\end{array}$ & 39 & ICU & [134] \\
\hline Morocco & 20 & 40 & Urinary isolates & [135] \\
\hline Pakistan & $\begin{array}{l}47.2 \text { (CAZ) } \\
59.7 \text { (CTZ) } \\
62.5 \text { (CRO) } \\
\end{array}$ & 72 & Medical ICU patient & [136] \\
\hline Pakistan & $\begin{array}{l}20.9(\mathrm{CTX}) \\
28.6(\mathrm{CAZ})\end{array}$ & 77 & Vaginal swab & [137] \\
\hline
\end{tabular}




\begin{tabular}{|c|c|c|c|c|}
\hline Pakistan & 71.4 & 56 & Urinary pathogens & [138] \\
\hline Pakistan & 31.2 & 15914 & Hospital samples & [139] \\
\hline Saudi Arabia & 19.9 & 9126 & Clinical isolates & [140] \\
\hline Saudi Arabia & $\begin{array}{c}13.7(\mathrm{HP}) \\
3.1(\mathrm{OP})\end{array}$ & $\begin{array}{c}225(\mathrm{HP}) \\
955\end{array}$ & Laboratory & [141] \\
\hline Saudi Arabia & $\begin{array}{l}589(\mathrm{CAZ}) \\
59(\mathrm{CRO})\end{array}$ & 96 & Laboratory record & [142] \\
\hline Tunisia & 46 & 4776 & Hospital samples & [143] \\
\hline United Arab Emirates & 42 & 45 & Hospital patient & [144] \\
\hline $\begin{array}{l}\text { Bosnia and } \\
\text { Herzegovina }\end{array}$ & 4.1 & 1553 & Urinary isolates (OP) & [145] \\
\hline $\begin{array}{l}\text { Bosnia and } \\
\text { Herzegovina }\end{array}$ & $\begin{array}{l}50 \text { (CTX); } \\
60 \text { (CRO); } \\
61.5 \text { (CAZ) }\end{array}$ & & Gynecology & [126] \\
\hline Bangladesh & $\begin{array}{c}97.8 \text { (CTX, CRO), } 82.2 \\
\text { (CAZ) }\end{array}$ & 45 & Blood isolates & [146] \\
\hline India & $\begin{array}{c}58 \text { (CTX) } \\
57 \text { (CAZ) } \\
100 \text { (CRO) }\end{array}$ & 173 & Blood isolates & [147] \\
\hline India & $\begin{array}{l}76.5(\mathrm{CRO}) \\
84.1 \text { (CAZ) }\end{array}$ & 125 & $\begin{array}{c}\text { Lower respiratory tract } \\
\text { infection (HP) }\end{array}$ & [148] \\
\hline Indonesia & $\begin{array}{l}53.3(\mathrm{CTX}) \\
67.2(\mathrm{CRO}) \\
\end{array}$ & 67 & Blood isolates & [149] \\
\hline Nepal & 48.3 & 145 & Urinary isolates & [150] \\
\hline Mongolia & $\begin{array}{l}33.7 \text { (CTX) } \\
27.4 \text { (CAZ) }\end{array}$ & 92 & Community infection & [151] \\
\hline Singapore & $\begin{array}{l}32.3(\mathrm{AI}) \\
27.4(\mathrm{BI})\end{array}$ & $\begin{array}{c}6321(\mathrm{AI}) \\
585(\mathrm{BI})\end{array}$ & Hospital Network & [11] \\
\hline Iran & 41.1(CRO) & 90 & Hospital samples & [152] \\
\hline Ethiopia & $82.5 \%(\mathrm{CTX})$ & 3229 & Hospital samples & [153] \\
\hline
\end{tabular}

Note: $\mathrm{CAZ}=$ Ceftazidim; $\mathrm{CTX}=$ Cefotaxim; $\mathrm{CRO}=$ Ceftriaxone), $\mathrm{Com}=$ Community, Hosp= Hospital, HP= Hospital patient, $\mathrm{OP}=$ Outpatients, $\mathrm{AI}=$ All isolates, $\mathrm{BI}=\mathrm{Blood}$ isolates

Table 3. Klebsiella pneumoniae: Selected literature on resistance to carbapenem

\begin{tabular}{|c|c|c|c|c|}
\hline Countries & Resistance\% & Isolates & Samples type & References \\
\hline Brazil & 0 (IMI); $1.6(\mathrm{ETP})$ & 63 & Clinical samples & {$[154]$} \\
\hline Trinidad and Tobago & 0 & 92 & Hospitalized children & {$[155]$} \\
\hline Iraq & 0 & 30 & BI (Neonate ICU) & $[131])$ \\
\hline Lebanon & $1.8(\mathrm{DOR}) ; 8.8(\mathrm{IMI})$ & 57 & Hospital samples & {$[133]$} \\
\hline Pakistan & 20.8 & 72 & Medical ICU patients & {$[136]$} \\
\hline Pakistan & 0.4 & 5016 & Hospital samples & {$[139]$} \\
\hline Israel & 7 & 299 & Patient screening & {$[156]$} \\
\hline Bangladesh & 0 & 45 & Blood isolates (neonates) & {$[146]$} \\
\hline India & $39.4(\mathrm{IMI}) ; 36.5(\mathrm{MEM})$ & 104 & Blood isolates & {$[157]$} \\
\hline Saudi Arabia & 0.4 & 285 & ICUs & {$[158]$} \\
\hline Saudi Arabia & 7.8 & 128 & Hospital isolates & {$[159]$} \\
\hline Turkey & 0 & 18 & Burn patients & {$[160]$} \\
\hline India & 18.6 & 327 & UTI (HP) & {$[161]$} \\
\hline Ethiopia & $92.5(\mathrm{IMI}), 92.5(\mathrm{MEM})$ & 3229 & Hospital isolates & {$[153]$} \\
\hline
\end{tabular}

Note: $\mathrm{MEM}=$ Meropenem; Dor= Doripenem; ETP= Ertapenem; IMI= Imipenem, UTI= Urinary tract Infections, HP= Hospital patients 


\section{Treatment of Klebsiella pneumoniae infections}

Suitable health-giving opportunities are frequently determined founded on the $\mathrm{AB}$ range, expediency of usage and adequacy of $\mathrm{AB}$, such as $3^{\text {rd }}$ and $4^{\text {th }}$ generation cephalosporin. Aminoglycosides are used in combination therapy with beta- lactam antibiotics. Therefore, it is expected to reveal high rate of resistance to aminoglycosides as well as beta-lactams [163]. The applicable AB treatment is reliant on vulnerability forms of native bacterial and hazard side view of patient, which may eventually control the risk of infection with opportunistic and possibly ABR infections [96]. MDR bacterial strains, such as Klebsiella pneumoniae, Acinetobacter baumannii and Pseudomonas aeruginosa existing a health-giving challenge owed towards their capacity to weaken handling, while too decreasing suitable $A B$ choices existing and producing a deferral in proper dealing due to ineffective experiential treatment $[97,98]$.

\subsection{Treatment of multidrug-resistant Klebsiella pneumoniae infections}

The worldwide development of MDR Grams negative bacilli is an incomparable problematic, which is impaired by the focus on refining current classes of $A B$ in its place of evolving novel classes of drugs with changed marks resolved the 49 years earlier [99, 100]. The increase amount of MDR microorganisms and the progressively inadequate handling options is established by ever predominant ESBL-producing Klebsiella pneumoniae for which carbapenem stood the support treatment but are progressively reduced useless via the infrequent rise of carbapenem-resistant enterobacteriaceae [101-102]. Usual appearances of ESBL-producing members of the enterobacteriaceae family comprise resistance to amino- and carboxypenicillins, $2^{\mathrm{ND}}$ and several $3^{\text {rd }}$ and $4^{\text {th }}$ generation of cephalosporins in accumulation to monobactams (such as aztreonam) however about might persist vulnerable to cephamycins [27, 103-105]. ESBL and clavulanate, a $\beta \mathrm{L}$ inhibitor, and might display further resistance to additional $\mathrm{AB}$, such as fluoroquinolones, aminoglycosides, trimethoprim and sulphamethoxa- zoles [20, 103, 106]. Experiential treatment must contest data on pathogens dispersed in the medical location and their predisposition forms thus as to well confirm exact early $A B$ treatment. Late suitable treatment can increase the possibility of expiry [107]. In a retroactive study led through Micek et al., [96] a fine significance was expected to be related by exact initial combination $\mathrm{AB}$ treatment when empirically treating gram negative bacteria by mediated sepsis as related to monotherapy. A combination of as ciprofloxacin, or an aminoglycosides with or cefepime, carbapenem (imipenem and MEM), as primary handling for severe gram negative bacterial infections current a widespread range of action. 92 Further reviewing studies additional favor combination cure in CRE infections used for which treatment choices have been compact mostly to colistin, tigecycline about aminoglycosides and fosfomycin (FFC) [99, 102]. While FFC seems lively in vitro, now is small therapeutic knowledge by the $\mathrm{AB}$ in addition to information of acceptable combinations for treatment lacking inspiring ABR [99, 108, 109]. TCL has established productivity against MDR enterobacteriaceae and uniform with requiring medicine changes, due to little level of blood, has good medical practices $[99,106$, 110]. A disastrous disadvantage to TCL might comprise the collection of gram negative bacteria with efflux pump alterations [100, 106]. Colistin has been suggested for usage first in cases of recognized nosocomial or MDR strains and ICU late sepsis tremor anywhere strains of MDR are assumed [99]. The practice of colistin for a persistent retro (>13 days) of time has been suggested as liable for the rise of colistin resistant or in some 
cases of bacterial strain having pandrugresistant [111-113]. The rise of strains that producing KPC in Klebsiella pneumoniae has reduced the resistant to wholly nonetheless unique AB i.e. colistin [114].

\section{Spread, prevention and control}

The increase in ABR between bacteria, such as those definite as 'ESKAPE' pathogens (Enterococcus faecium, Staphylococcus aureus, $K$. pneumoniae, A. baumannii, $P$. aeruginosa and Enterobacter spp.), has emphasized the vital aimed at new $A B$ owed toward the 'escape' after currently promoted AB drugs [115]. The influence of infections by $\beta$-lactamase producing bacteria comprise improved rates of death mainly in blood stream infections (BSI), and rise in measurement of expenses in hospitalization and sickbay. Value lakes usually concerned in healthcare related occurrences or extent comprises the patients, the well-being maintenance worker and the surroundings (such as sink drains) [116]. Influences impacting the extent and regulator of MDR bacteria contain feast of plasmids and are compressed via the nutrition chain or worldwide travel [117]. In the journeys, acquirement can arise in the time off healthcare contact otherwise with rest and medicinal tourism [118, 119].

In places of healthcare, overfilling is a significant influence in impairing the faecal oral way of spread through direct or incidental interaction by healthcare staffs [120]. The connection that staff have by patients during uncertain community contacts, such as taking a patient's blood pressure and the touching of extinct matters in the patient's atmosphere, could give to level spread of pathogens, particularly when elective hand sterility practices are unnoticed [99, 121]. The application of alcohol built hand scrubs and even instructive programs are so significant phases in regulator actions assumed [121]. Infection control actions assumed can contain: (i) improved barrier safety measures, (ii) separation of sick patients, (iii) suitable $A B$ handling period (iv) epidemiological principles for the management of apparatus and patient lesions $[2,99]$.

A technique explored aimed at its prospective to decrease irritated infection amounts in medical locations, like ICU, is the consequence of selective digestive tract decontamination (SDD) for the removal of cephalosporin-resistant enterobacteriaceae [122-124]. Numerous key inadequacies have, still, been recognized by the WHO in the conflict contrary to ABR. This problem is conferred below 4 issues which comprise: (i) absence of assurance and data, (ii) unverified $A B$ value and unreasonable usage, (iii) reduced inhibition and control of infections (iv) failing investigation into novel $A B$ apparatuses and agents, comprising analytical trials and $\mathrm{AB}$. The subsequent strategy set suggested through the WHO so initially recommends that administrations assume and economics inclusive state plans with liability and likable public civilization by building community alertness.

Another approval is constructed on refining investigation and test site volumes, whereas the 3 rd recommends native administrations to assurance a continuous source of needed, value secure medication. The instruction and raise of the precise use of earlier stated medicine is too highlighted beside with good patient care. Lastly, the last 2 approvals include control though inspiring research, improvement in prevention of infection and improvement of new tools, containing diagnostic tests and $\mathrm{AB}$ [125].

\section{Conclusion}

Bacteria such as Klebsiella spp. are adapted to harsh surroundings formed through the usage of antibiotics concluded numerous mechanisms, which comprise the appearance of $\beta$-Lactam proficient of hydrolyzing penicillin's along with another $\beta$-lactam antibiotics. ESBL producing Klebsiella pneumoniae forms part of the ESBL 
producing enterobacteriaceae, together which is recorded as single of 6 hazardous pathogens by the Infectious Disease Society of America collected with ESKAPE (Enterococcus faecium, Staphylococcus aureus, Klebsiella pneumoniae, Acinetobacter baumannii, Pseudomonas aeruginosa, and Enterobacter species)'. Antibiotics resistance is frequently conversed in terms of range and succeeding production of MDR strains or the chromosomes and plasmids which are the components horizontal transmission of genome encoding resistance. A numeral of indications on or after studies crossways the world show that MDR bacteria are evolving global producing numerous community health problems and tasks to healthcare. The incidence of drug resistance owed to Klebsiella pneumoniae approaches $60 \%$ in around states, with largely high proportions all around the globe. The misuse of antibiotics is creating superbugs, which is a lethal threat to the community and public health. Search of alternative antibiotics and the redressal to drug resistance against commonly in use antibiotics are the need of day.

\section{Authors' contributions}

Conceived and designed the Idea: F Liaqat, M Shafee \& Ali Akbar, Analyzed the Idea: F Liaqat, W Naeem, M Anwar, H Sadia \& D Ghilzai, Wrote the paper: F Liaqat, A Akbar \& M Shafee.

\section{Acknowledgement}

The study was partially supported by the funds from AIP-PARC-2017 USAID, NRPU-HEC 6470 and UBRF-2017 University of Balochistan Quetta.

\section{References}

1. Brisse $\mathrm{S}$, Grimont $\mathrm{F} \&$ Grimond $\mathrm{P}$ (2006). The genus Klebsiella. In: Dworkin M, Falkow S, Rosenberg E, Schleifer KH \& Stackebrandt E, editors. The prokaryotes proteobacteria: Gamma Subclass, 3rd edition, Springer, New York, NY, pp. 159-196.
2. Podschun R \& Ullmann U (1998). Klebsiella spp. as nosocomial pathogens: epidemiology, taxonomy, typing methods and pathogenicity factors. Clinic Microbiol Rev 11: 589603.

3. Dillon RJ, Vennard CT \& Charnley AK (2002). A note: gut bacteria produce components of a locust cohesion pheromone. J Appl Microbiol 92(4): 759-763.

4. Broberg CA, Palacios M \& Miller VL (2014). Klebsiella: a long way to go towards understanding this enigmatic jet-setter. F1000Prime Rep 6: 64 .

5. Cristea OM, Avrămescu CS, Bălășoiu M, Popescu FD, Popescu F \& Amzoiu MO (2017). Urinary tract infection with Klebsiella pneumoniae in Patients with Chronic Kidney Disease. Curr Health Sci J 43(2): 137-148.

6. Hansen DS, Gottschau A \& Kolmos HJ (1998). Epidemiology of Klebsiella bacteraemia: a case control study using Escherichia coli bacteraemia as control. J Hosp Infect 38(2): 119-132.

7. Tsai FC, Huang YT, Chang LY \& Wang JT (2008). Phylogenic liver abscess as endemic disease, Taiwan. Emerg Infect Dis 14: 1592-600.

8. Yeh KM , Kurup A, Siu LK, Koh YL, Fung CP, Lin JC, Chen TL, Chang FY \& Koh TH (2007). Capsular serotype $\mathrm{K} 1$ or $\mathrm{K} 2$, rather than magA and rmpA, is a major virulence determinant for Klebsiella pneumoniae liver abscess in Singapore and Taiwan. $J$ Clin Microbiol 45: 466-71.

9. Lee SY, Kotapati S, Kuti JL, Nightingale CH \& Nicolau DP (2006). Impact of extended-spectrum betalactamase-producing Escherichia coli and Klebsiella spp. On clinical outcomes and hospital costs: a matched cohort study. Infect Control Hosp Epidemiol 27: 1226-32. 
10. Maayan MC, Ofek I, Medalia O \& Aronson M (1985). Population shift in mannose-specific fimbriated phase of Klebsiella pneumoniae during experimental urinary tract infection in mice. Infect Immun 49(3): 785-789.

11. Hsu LY, Tan TY, Tam VH, Kwa A, Fisher DA, Koh TH \& The Network for Antimicrobial Resistance Surveillance (Singapore) (2010). Surveillance and correlation of antibiotic prescription and resistance of Gram-negative bacteria in Singaporean hospitals. Antimicrob Agents Chemother 54(3): 1173-1178.

12. Mizuta K, Ohta M, Mori M, Hasegawa T, Nakashima I \& Kato N (1983). Virulence for mice of Klebsiella strains belonging to the $\mathrm{O} 1$ group: relationship to their capsular $(\mathrm{K})$ types. Infect Immun 40(1): 56-61.

13. Cusa E, Obradors N, Baldomà L, Badía J \& Aguilar J (1999). Genetic analysis of a chromosomal region containing genes required for assimilation of allantoin nitrogen and linked glyoxylate metabolism in Escherichia coli. J Bacteriol 181(24): 7479-7484.

14. Mobley HL, Island MD \& Hausinger RP (1995). Molecular biology of microbial ureases. Microbiol Rev 59(3): 451-480.

15. Maroncle N, Rich C \& Forestier C (2006). The role of Klebsiella pneumoniae urease in intestinal colonization and resistance to gastrointestinal stress. Res Microbiol 157(2): 184-193.

16. Ma LC, Fang CT, Lee CZ, Shun CT \& Wang JT (2005). Genomic heterogeneity in Klebsiella pneumoniae strains is associated with primary pyogenic liver abscess and metastatic infection. $J$ Infect Dis 192(1): 117-128.
17. Fernández L, Breidenstein EBM \& Hancock REW (2011). Creeping baselines and adaptive resistance to antibiotics. Drug Resist Update 14: 121.

18. Poole K (2012). Bacterial stress responses as determinants of antimicrobial resistance. J Antimicrob Chemother 67: 2069-89.

19. Bernier SP, Lebeaux D, DeFrancesco AS, Valomon A, Soubigou G, Coppée JY, Ghigo JM \& Beloin C (2013). Starvation, together with the SOS response, mediates high biofilmspecific tolerance to the fluoroquinolone ofloxacin. PLoS Genet 9: e1003144.

20. Kumar V, Sun P, Vamathevan J, Li Y, Ingraham K, Palmer L, Huang J \& Brown JR (2011). Comparative genomics of Klebsiella pneumoniae strains with different antibiotic resistance profiles. Antimicrob Agent Chemother 55: 4267-76.

21. Poole K (2004). Efflux-mediated multiresistance in Gram-negative bacteria. Clin Microbiol Infect 10: 1226.

22. Kocsis B \& Szabo D (2013). Antibiotic resistance mechanisms in Enterobacteriaceae. In: A MéndezVilas, editor. Microbial pathogens and strategies for combating them: science, technology and education. Spain: Formatex Research Center 251-257.

23. Poole K (2005). Efflux-mediated antimicrobial resistance. J Antimicrob Chemother 56: 20-51.

24. Mazzariol A, Zuliani J, Cornaglia G, Rossolini GM \& Fontana R (2002). AcrAB efflux system: expression and contribution to fluoroquinolone resistance in Klebsiella spp. Antimicrob Agents Chemother 46: 3984-6. 
25. García-Sureda L, Juan C, DoménechSánchez A \& Albertí S (2011). Role of Klebsiella pneu- moniae LamB porin in antimicrobial resistance. Antimicrob Agents Chemother 55: 1803-5.

26. Ehlers MM, Veldsman C, Makgotlho EP, Dove MG, Hoosen AA \& Kock MM (2009). Detection of blaSHV, blaTEM, blaCTX-M antibiotic resistance genes in randomly selected bacterial pathogens from the Steve Biko Academic Hospital. FEMS Immonol Med Microbiol 56: 191-6.

27. Codjoe FS \& Donkor ES (2018). Carbapenem Resistance: A Review. Med Sci 6(1): 1

28. Campos MA, Vargas MA, Regueiro V, Llompart CM, Albertí S, \& Bengoechea JA (2004). Capsule polysaccharide mediates bacterial resistance to antimicrobial peptides. Infect Immunity 72: 7107-14.

29. Hennequin C, Aumeran C, Robin F, Traore O \& Forestier C (2012). Antibiotic resistance and plasmid transfer capacity in biofilm formed with a CTX-M-15-producing Klebsiella pneumoniae isolate. $J$ Antimicrob Chemother 67: 2123-30.

30. Mah TFC \& Toole GA (2001). Mechanisms of biofilm resistance to antimicrobial agents. Trends Microbiol 9: 34-9.

31. Soto SM (2013). Role of efflux pumps in the antibiotic resistance of bacteria embedded in a biofilm. Virulence 4: 223-9.

32. Ito A, Taniuchi A, May T, Kawata K \& Okabe S (2009). Increased antibiotic resistance of Escherichia coli in mature biofilms. Appl Environ Microbiol 75: 4093-100.

33. De AC, Balestrino D, Roth L, Charbonnel N \& Forestier C (2010). Quorum sensing affects biofilm formation through lipopolysaccharide synthesis in Klebsiella pneumoniae. Res Microbiol 161: 595-603.

34. Wilksch JJ, Yang J, Clements A, Gabbe JL, Short KR, Cao H, Cavaliere $\mathrm{R}$, James $\mathrm{CE}$, Whitchurch CB, Schembri MA, Chuah ML, Liang ZX, Wijburg OL, Jenney AW, Lithgow T \& Strugnell RA (2011). MrkH, a novel cdiGMP-dependent transcriptional activator, controls Klebsiella pneumoniae biofilm formation by regulating type 3 fimbriae expression. PLoS Pathogens 7: e1002204.

35. De C, Reffuveille F, Fernández L \& Hancock REW (2013). Bacterial biofilm development as a multicellular adaptation: antibiotic resistance and new therapeutic strategies. Curr Opin Microbiol 16: 580-9.

36. Bush K (2010). Bench to bedside review: the role of $\beta$-lactamases in antibiotic resistant Gram-negative infections. Criti Care 14: 224-31.

37. Ambler RP (1980). The structure of $\beta$ lactamases. Philos Transac Royal Soc London Biol Sci 289: 321-33.

38. Bush K \& Fisher JF (2012). Epidemiological expansion, structural studies and clinical chal- lenges of new $\beta$-lactamases from Gram-negative bacteria. Annu Rev Microbiol 65: 45578.

39. Samuelsen O, Naseer U, Tofteland S, Skutlaberg DH, Onken A, Hjetland R, Sundsfjord A \& Giske CG (2009). Emergence of clonally related Klebsiella pneumoniae isolates of sequence type 258 producing plasmidmediated KPC carbapenemase in Norway and Sweden. J Antimicrob Chemother 63: 654-8.

40. Grundmann H, Livermore DM, Giske CG, Canton R, Rossolini GM, Campos J, Vatopoulos A, Gniadkowski M, Toth A, Pfeifer Y, Jarlier V, Carmeli Y \& CNSE Working Group (2010). 
Carbapenem-non-susceptible

Enterobacteriaceae in Europe: conclusions from a meeting of national experts. Euro Surveill 15(46): 19711.

41. Bush A \& Jacoby GA (2010). Updated functional classification of betalactamases, Antimicrob Agents 54: 969-76.

42. Kliebe C, Nies BA, Meyer JF, Tolxdorff-Neutzling RM \& Wiedemann B (1985). Evolution of plasmid-coded resistance to broadspectrum cephalosporins. Antimicrob Agents 28: 302-7.

43. Navon-Venezia S, Hammer-Munz O, Schwartz D, Turner D, Kuzmenko B \& Carmeli Y (2003). Occurrence and phenotypic characteristics of extendedspectrum beta-lactamases among members of the family Enterobacteriaceae at the Tel-Aviv Medical Center (Israel) and evaluation of diagnostic tests. J Clin Microbiol 41: 155-8.

44. Canton R, Novais A, Valverde A, Machado E, Peixe L, Baquero F \& Coque TM (2008). Prevalence and spread extended-spectrum betalactamase producing Enterobacteriaceae in Europe. Clin Microbiol Infect 14: 144-53.

45. Chong Y, Ito Y \& Kamimura T (2011). Genetic evolution and clinical impact in extended-spectrum $\beta$-lactamaseproducing Escherichia coli and Klebsiella pneumoniae. Infect Genet Evol 11: 1499-504.

46. Calbo E \& Garau J (2015). The changing epidemiology of hospital outbreaks due to ESBL-producing Klebsiella pneumoniae: the CTX-M15 type consolidation. Future Microbiol 10: 1063-75.

47. Evans BA \& Amyes SGB (2014). OXA $\beta$-lactamases. Clin Microbiol Rev 27: 241-63.
48. Bradford PA (2001). Extendedspectrum beta-lactamases in the 21st century: characterization, epidemiology, and detection of this important resistance threat. Clin Microbiol Rev 14: 933-51.

49. Philippon A, Slama P, Deny P \& Labia R (2016). A structure-based classification of class A $\beta$-lactamases, a broadly diverse family of enzymes. Clin Microbiol Rev 29: 29-57.

50. WHO (2014) Antimicrobial Resistance, Global Report on Surveillance.

http://www.who.int/drugresistance/do cuments/surveillancereport/en/ March 2016, date last accessed).

51. Jacoby GA (2009).AmpC betalactamases. Clin Microbiol Rev 22: 161-82.

52. Livermore DM \& Woodford N (2006). The beta-lactamase threat in Enterobacteriaceae, Pseudomonas and Acinetobacter. Trends Microbiol 14: 413-20.

53. Queenan AM \& Bush K (2007). Carbapenemases: the versatile betalactamases. Clin Microbiol Rev 20: 440-58.

54. Chen L, Mathema B, Pitout JDD, DeLeo FR \& Kreiswirth BN (2014). Epidemic Klebsiella pneumoniae ST258 is a hybrid strain. mBio 5: e01355-1314.

55. Haruta S, Yamaguchi H, Yamamoto ET, Eriguchi Y, Nukaga M, O'Hara K \& Sawai T (2000). Functional analysis of the active site of a metallo-betalactamase proliferating in Japan. Antimicrob Agents 44: 2304-9.

56. Yigit H, Queenan AM, Anderson GJ, Domenech-Sanchez A, Biddle JW, Steward CD, Alberti S, Bush K \& Tenover FC (2001). Novel carbapenem hydrolyzing beta-lactamase, KPC-1, from a carbapenem-resistant strain of 
Klebsiella pneumoniae. Antimicrob Agents Chemother 45: 115161.

57. Poirel L, Heritier C, Tolun V \& Nordmann P (2004). Emergence of oxacillinase- mediated resistance to imipenem in Klebsiella pneumoniae. Antimicrob Agents 48: 15-22.

58. Yong D, Toleman MA, Giske CG, Cho HS, Sundman K, Lee K \& Walsh TR (2009). Characterization of a new metallo-beta-lactamase gene, blaNDM-1, and a novel erythromycin esterase gene carried on a unique genetic structure in Klebsiella pneumoniae sequence type 14 from India. Antimicrob Agents 53: 5046-54.

59. Mathers AJ, Peirano G \& Pitout JDD (2015). The role of epidemic resistance plasmids and international high-risk clones in the spread of multidrugresistant Enterobacteriaceae. Clin Microbiol Rev 28: 565-91.

60. Kitchel B, Rasheed JK, Patel JB, Srinivasan A, Navon-Venezia S, Carmeli Y, Brolund A \& Giske CG (2009). Molecular epidemiology of KPC-producing Klebsiella pneumoniae isolates in the United States: clonal expansion of multilocus sequence type 258. Antimicrob Agents 53: 3365-70.

61. Munoz-Price LS, Poirel L, Bonomo RA, Schwaber MJ, Daikos GL, Cormican M, Cornaglia G, Garau J, Gniadkowski M, Hayden MK, Kumarasamy K, Livermore DM, Maya JJ, Nordmann P, Patel JB, Paterson DL, Pitout J, Villegas MV, Wang H, Woodford N \& Quinn JP (2013). Clinical epidemiology of the global expansion of Klebsiella pneumoniae carbapenemases. Lancet Infect Dis 13: 785-96.

62. Naas T, Cuzon G, Truong HV \& Nordmann P (2012). Role of ISKpn7 and deletions in blaKPC gene expression. Antimicrob Agents 56: 4753-9.

63. Chmelnitsky I, Shklyar M, Leavitt A, Sadovsky E, Navon-Venezia S, Ben Dalak M, Edgar R \& Carmeli Y (2014). Mix and match of KPC-2 encoding plasmids in Enterobacteriaceaecomparative genomics. Diagn Micr Infec Dis 79: 25560.

64. Sidjabat HE, Silveira FP, Potoski BA, Abu-Elmagd KM, Adams-Haduch JM, Paterson DL \& Doi Y. (2009). Interspecies spread of Klebsiella pneumoniae carbapenemase gene in a single patient. Clin Infect Dis 49: 17368.

65. Papp-Wallace KM, Bethel CR, Distler AM, Kasuboski C, Taracila M \& Bonomo RA (2010). Inhibitor resistance in the KPC-2 betalactamase, a preeminent property of this class A beta-lactamase. Antimicrob Agents 54: 890-7.

66. Van de Klundert JA, van Gestel MH, Meerdink G \& de-Marie S. (1988). Emergence of bacterial resistance to cefamandole in vivo due to outer membrane protein deficiency. Eur $J$ Clin Microbiol 7: 776-8.

67. Leavitt A, Chmelnitsky I, Colodner R, Ofek I, Carmeli Y \& Navon-Venezia S (2009). Ertapenem resistance among extended-spectrum-beta-lactamaseproducing Klebsiella pneumoniae isolates. J Clin Microbiol 47: 969-74.

68. Padilla E, Llobet E, DomenechSanchez A, Martínez-Martínez L, Bengoechea JA, \& Albertí S (2010). Klebsiella pneumoniae AcrAB efflux pump contributes to antimicrobial resistance and virulence. Antimicrob Agents 54: 177-83.

69. Wachino J, Doi Y, Yamane K, Shibata N, Yagi T, Kubota T \& Arakawa Y (2004). Molecular characterization of a cephamycin-hydrolyzing and 
inhibitor-resistant class A betalactamase, GES-4, possessing a single G170S substitution in the omega-loop. Antimicrob Agents 48: 2905-10.

70. Lee CR, Lee JH, Park KS, Kim YB, Jeong BC, \& Lee SH (2016). Global dissemination of carbapenemaseproducing Klebsiella pneumoniae: epidemiology, genetic context, treatment options, and detection methods. Front Microbiol 7: 895.

71. Moland ES, Hong SG, Thomson KS, Larone DH \& Hanson ND (2007). Klebsiella pneumoniae isolate producing at least eight different betalactamases, including AmpC and KPC beta-lactamases. Antimicrob Agents 51: 800-1.

72. Doi YO, Hara JA, Lando JF, Querry AM, Townsend BM, Pasculle AW \& Muto CA (2014). Co-production of NDM- 1 and OXA-232 by Klebsiella pneumoniae. Emerg Infect Dis 20: 1635.

73. Molton JS, Tambyah PA, Ang BSP, Querry AM, Townsend BM, Pasculle AW \& Muto CA (2013). The global spread of healthcare-associated multidrug-resistant bacteria: a perspective from Asia. Clin Infect Dis 56: 1310-8.

74. Huang $T$, Chen TL, Chen YT, Lauderdale TL, Liao TL, Lee YT, Chen CP, Liu YM, Lin AC, Chang YH, Wu KM, Kirby R, Lai JF, Tan MC, Siu LK, Chang CM, Fung CP \& Tsai SF (2013). Copy number change of the NDM-1 sequence in a multidrugresistant Klebsiella pneumoniae clinical isolate. PLoS One 8: e62774.

75. Krause KM, Serio AW, Kane TR \& Connolly LE (2016). Aminoglycosides: an overview. Cold Spring Harb Perspect Med 6. DOI: 10.1101/cshperspect.a027029.
76. Doi Y, Wachino J \& Arakawa Y (2016). Aminoglycoside resistance: the emergence of acquired $16 \mathrm{~S}$ ribosomal RNA methyltransferases. Infect Dis Clin N Am 30: 523-37.

77. Galimand M, Courvalin P \& Lambert T (2003). Plasmid-mediated highlevel resistance to aminoglycosides in Enterobacteriaceae due to $16 \mathrm{~S}$ rRNA methylation. Antimicrob Agents 47: 2565-71.

78. Poulikakos P \& Falagas ME (2013). Aminoglycoside therapy in infectious diseases. Expert Opin Pharmaco 14: 1585-97.

79. Yu F, Wang L, Pan J, Yao D, Chen C, Zhu T, Lou Q, Hu J, Wu Y, Zhang X, Chen Z \& Qu D (2009). Prevalence of $16 \mathrm{~S}$ rRNA methylase genes in Klebsiella pneumoniae isolates from a Chinese teaching hospital: coexistence of $\mathrm{rmtB}$ and armA genes in the same isolate. Diagn Micr Infec Dis 64: 5763.

80. Srinivasan VB \& Rajamohan G (2015). KpnEF, a new member of the Klebsiella pneumoniae cell envelope stress response regulon, is determinant among members of Enterobacteriaceae. Antimicrob Agents 59: 3290-7.

81. Beceiro A, Tomas M \& Bou G (2013). Antimicrobial resistance and virulence: a successful or deleterious association in the bacterial world. Clin Microbiol Rev 26: 185-230.

82. Tsai YK, Liou CH, Lin JC, Ma L, Fung CP, Chang FY \& Siu LK (2014). A suitable streptomycinresistant mutant for constructing unmarked in-frame gene deletions using rpsL as a counterselection marker. PLoS One 9: e109258.

83. Naeem A, Badshah SL, Muska M, Ahmad N \& Khan K (2016). The current case of quinolones: synthetic 
approaches and antibacterial activity. Mol Basel 21:268.

84. Redgrave LS, Sutton SB, Webber MA \& Piddock LJ (2014). Fluoroquinolone resistance: mechanisms, impact on bacteria, and role in evolutionary success. Trends Microbiol 22: 438-45.

85. Ward-McQuaid JF, Jichlinski D \& Macis R (1963). Nalidixic acid in urinary infections. $\mathrm{Br}$ Med J 2: 13114.

86. Guerra JG, Falconi E, Palomino JC, Benavente L \& Antunez de Mayolo E (1983). Clinical evaluation of norfloxacin versus cotrimoxazole in urinary tract infections. Eur J Clin Microbial 2: 260-5.

87. Schedlbauer A, Kaminishi T, OchoaLizarralde B, Dhimole N, Zhou S, López-Alonso JP, Connell SR \& Fucini P (2015). Structural characterization of an alternative mode of tigecycline binding to the bacterial ribosome. Antimicrob Agents 59: 2849-54.

88. Golan Y (2015). Empiric therapy for hospital-acquired, Gram-negative complicated intra-abdominal infection and complicated urinary tract infections: a systematic literature review of current and emerging treatment options. BMC Infect Dis 15: 313.

89. Ruzin A, Visalli MA, Keeney D $\&$ Bradford PA (2005). Influence of transcriptional activator RamA on expression of multidrug efflux pump AcrAB and tigecycline susceptibility in Klebsiella pneumonia. Antimicrob Agents 49: 1017-22.

90. Osei SJ, Govinden U, Bester LA \& Essack SY (2016). Colistin and tigecycline resistance in carbapenemase-producing

Gramnegative bacteria: emerging resistance mechanisms and detection methods. J Appl Microbiol 121: 60117.

91. Chopra I \& Roberts M (2001). Tetracycline antibiotics: mode of action, applications, molecular biology, and epidemiology of bacterial resistance. Microbiol Mol Biol Rev 65(2): 232-60.

92. Patterson AJ, Rincon MT, Flint HJ \& Scott KP (2007). Mosaic tetracycline resistance genes are widespread in human and animal fecal samples. Antimicrob Agents Chemother 51(3): 1115-8.

93. Ross JI, Eady EA, Cove JH \& Cunliffe WJ (1998). 16S rRNA mutation associated with tetracycline resistance in a gram-positive bacterium. Antimicrob Agents Chemother 42(7): 1702-5.

94. Pitout JDD, Nordmann P \& Poirel L (2015). Carbapenemase-producing Klebsiella pneumoniae, a key pathogen set for global nosocomial dominance. Antimicrob Agents 59: 5873-84.

95. Seiffert SN, Marschall J, Perreten V, Carattoli A4, Furrer H \& Endimiani A (2014). Emergence of Klebsiella pneumoniae co-producing NDM-1, OXA-48, CTX-M-15, CMY-16, QnrA and ArmA in Switzerland. Int $J$ Antimicrob Agents., 44: 260-2.

96. Micek ST, Welch EC, Khan J, Pervez M, Doherty JA, Reichley RM \& Kollef MH (2010). Emperic combination antibiotic therapy is associated with improved outcome against sepsis due to Gram-negative bacteria: a retrospective analysis. Antimicrob Agents Chemo ther 54: 1742-8.

97. Woodford N, Turton JF \& Livermore DM (2011). Multiresistant Gramnegative bacteria: the role of high-risk clones in the dissemination of antibiotic resistance. FEMS Microbiol Rev 35: 736-55. 
98. Vaara M (2010). Polymyxins and their novel derivatives. Curr Opin Microbiol 13: 574- 81 .

99. Giamarellou H (2010). Multidrugresistant Gram-negative bacteria: how to treat and for how long. Int $J$ Antimicrob Agents 36: S50-4.

100. Bush K (2012). Improving known classes of antibiotics: an optimistic approach to the future. Curr Opin Pharmacol 12: 527-34.

101. Gasink LB, Edelstein PH, Lautenbach E, Synnestvest M \& Fishman NO (2009). Risk factors and clinical impact of Klebsiella pneumoniae carbapenemase-producing $K$. pneumonia. Infection control and hospital epidemiology. 30, 1180-5.

102. Van DD, Kaye KS, Neuner EA \& Bonomo RA (2013). Carbapenemresistant Enterobacteriaceae: a review of treatment and outcomes. Diagnost Microbiol Infect Dis 75: 115-20.

103. Drieux L, Brossier F, Sougakoff W \& Jarlier V (2008). Phenotypic detection of extended-spec- trum $\beta$-lactamase production in Enterobacteriaceae: review and bench guide. Clin Microbiol Infect 14: 90-103.

104. Lee JH, Bae IK \& Lee SH (2012). New definitions of extended-spectrum $\beta$ lactamase confer- ring worldwide emerging antibiotic resistance. Med Res Rev 32: 216-32.

105. Breurec S, Guessennd N, Timinoni M, Le $T$, Cao V, Ngandjio A, Randrianirina F, Thiberge JM, Kinana A, Dufougeray A, Perrier-Gros-Claude JD, Boisier P, Garin B \& Brisse S (2013). Klebsiella pneumoniae resistant to third generation cephalosporins in five African and two Vietnamese major towns: multiclonal population structure with two major interna- tional clonal groups, CG15 and CG258. Clin Microbiol Infect 19: 349-55.

106. Giske CG, Monnet DL, Cars O \& Carmeli Y (2008). Clinical and economic impact of common multidrug-resistant Gramnegative bacilli. Antimicroal AgentChemother 52: 813-21.

107. Souli M, Galani I, Antoniadou A, Papadomichelakis E, Poulakou G, Panagea $\mathrm{T}$ Vourli S, Zerva L, Armaganidis A, Kanellakopoulou K \& Giamarellou H. (2010). An outbreak of infection due to beta-lactamase Klebsiella pneumoniae Carbapenemase 2-producing $\mathrm{K}$. pneumoniae in a Greek University Hospital: molecular characterization, epidemiology, and outcomes. Clin Infect Dis 50(3): 364-73.

108. Falagas ME, Maraki S, Karageorgopoulos DE, Kastoris AC, Mavromanolakis E \& Samonis G (2010). Antimicrobial susceptibility of multidrug-resistant (MDR) and extensively drug resistant (XDR) Enterobacteriaceae isolates to fosfomycin. Int J Antimicrob Agents 35: 240-3.

109. Raz R (2010). Fosfomycin: An oldnew antibiotic. Clin Microbiol Infect 18: 4-7.

110. Souli M, Kontopidou FV, Koratzanis E, Antoniadou A, Giannitsioti E, Evangelopoulou P, Kannavaki S \& Giamarellou H (2006). In vitro activity of tigecycline against multipledrugresistant, including pan-resistant, Gram-negative and Gram-positive clinical isolates from Greek hospitals. Antimicrob Agents Chemother 50: 3166-9.

111. Brink AJ, Coetzee J, Corcoran C, Clay CG, Hari-Makkan D, Jacobson RK, Richards GA, Feldman C, Nutt L, van Greune J, Deetlefs JD, Swart K, 
Devenish L, Poirel L \& Nordmann P (2013). Emergence of OXA-44 and OXA-181 carbapenemases among Enterobacteriaceae in South Africa and evidence of in vivo selection of colistin resistance as a consequence of selective decontamination of the gastrointestinal tract. J Clin Microbiol 51, 369-72.

112. Antoniadou A, Kontopidou F, Poulakou G, Koratzanis E, Galani I, Papadomichelakis E, Kopterides P, Souli M, Armaganidis A \& Giamarellou H (2007). Colistinresistant isolates Klebsiella pneumoniae emerging in intensive care unit patients: first report of a multiclonal cluster. $J$ Antimicrob Chemother 59: 786-90.

113. Nahid F, Zahra R \& Sandegren L (2017). A blaOXA-181-harbouring multi-resistant ST147 Klebsiella pneumoniae isolate from Pakistan that represent an intermediate stage towards pan-drug resistance. PLoS ONE 12(12): e0189438.

114. Souli M, Kontopidou FV, Papadomichelakis E, Galani I, Armaganidis A \& Giamarello $\mathrm{H}$ (2008). Clinical experience of serious infections caused by Enterobacteriaceae producing VIM-1 metallo-beta-lactamases in a Greek university hospital. Clin Infect Dis 46: 847-54.

115. Boucher HW, Talbot G, Bradley JS, Edwards JE, Gilbert D, Rice LB, Scheld M, Spellberg B \& Bartlett J. (2009). Bad bugs, no drugs: no ESKAPE! An update from the Infectious Diseases Society of America. Clin Infect Dis 48: 1-12.

116. Tofteland S, Naseer U, Lislevand JH, Sundsfjord A \& Samuelsen O (2013). A long-term lowfrequency hospital outbreak of KPC-producing Klebsiella pneumoniae involving intergenus plasmid diffusion and a persisting environmental reservoir. PLOS ONE 8: e59015.

117. Kluytmans MF \& Kluytmans JA (2012). Editorial commentary: control of multidrug-resistant microorganisms: beyond the hospital. Clin Infect Dis 55: 1512-4.

118. Van AK \& Pitout JDD (2012). The role of international travel in the worldwide spread of multiresistant Enterobacteriaceae. $J$ Antimicrob Chemother 67: 2090-100.

119. Rogers BA, Aminzadeh Z, Hayashi Y \& Paterson DL (2011). Country-tocountry transfer of patients and the risk of multi-resistant bacterial infection. Clin Infect Dis 53: 49- 56.

120. Ghafourian S, Sadeghifard N, Soheili S \& Sekawi Z (2014). Extended spectrum beta-lactamases: definition, classification and epidemiology. Curr Issues Molecul Biol 17: 11- 22.

121. Allegranzi B \& Pittet D (2009). Role of hand hygiene in healthcare-associated infection pre- vention. J Hospital Infect 73: 305-15.

122. De Smet AM, Kluytmans JA, Blok HE, Mascini EM, Benus RF, Bernards AT Kuijper EJ, Leverstein-van Hall MA, Jansz AR, de Jongh BM, van Asselt GJ, Frenay IH, Thijsen SF, Conijn SN, Kaan JA, Arends JP, Sturm PD, Bootsma MC \& Bonten MJ (2011). Selective digestive tract decontamination and selective oropharyngeal decontamination and antibiotic resistance in patients in intensive-care units: an open-label, clusters group-randomised, crossover study. Lancet Infect Dis 11: 372-80.

123. Oostdijk EA, De Smet AM, Kesecioglu J, Bonten MJ \& Dutch SOD-SDD Trialists Group (2011). The role of intestinal colonisation with Gram- 
negative bacteria as a source for intensive care unit-acquired bacteremia. Crit Care Med 39: 961-6.

124. Oostdijk EA, De Smet AM, Kesecioglu J \& Bonten MJ (2012). Decontamination of cephalosporinresistant Enterobacteriaceae during selective digestive tract decontamination in intensive care units. J Antimicrob Chemother 67: 2250-3.

125. Leung E, Weil DE, Raviglione M \& Nakatani H (2011). World Health Organisation World Health Day Antimicrobial Resistance Technical Working Group. The WHO policy package to combat antimicrobial resistance. Bull World Health Organizat 89: 390-2.

126. Custović A, Zulcić-Naki V, Ascerić M $\&$ Hadzić S (2009). Surveillance of intrahospital infections at the clinic for gynaecology and obstetrics. Bosn J Basic Med Sci 9(1): 66-70.

127. Akpaka PE \& Swanston WH (2008). Phenotypic detection and occurrence of extended-spectrum beta-lactamases in clinical isolates of Klebsiella pneumoniae and Escherichia coli at a tertiary hospital in Trinidad \& Tobago. Braz J Infect Dis 12(6): 516-520.

128. Superti SV, Augusti G \& Zavascki AP (2009). Risk factors for and mortality of extended-spectrum-beta-lactamase producing Klebsiella pneumoniae and Escherichia coli nosocomial bloodstream infections. Rev Inst Med Trop Sao Paulo 51(4): 211-216.

129. Garza-González E, Llaca-Díaz J, Bosques-Padilla F \& González G (2010). Prevalence of multidrugresistant bacteria at a tertiary-care teaching hospital in Mexico: special focus on Acinetobacter baumannii. Chemother 56(4): 275-279.
130. Mahmood I, Jarjees $\mathrm{Y} \&$ Satam $\mathrm{Z}$ (2012). In vitro resistance to cephalosporins in women with bacterial urinary tract infections. Iraqi Post Grad J 11: 321-325.

131. Al-Talib H, Al-Khateeb A \& AlKhalidi RN (2013). Neonatal septicemia in neonatal intensive care units: Epidemiological and microbiological analysis of causative organisms and antimicrobial susceptibility. Int Med J 20(1): 36-40.

132. Al-Benwan K, Al Sweih N \& Rotimi VO (2010). Etiology and antibiotic susceptibility patterns of communityand hospital-acquired urinary tract infections in a general hospital in Kuwait. Med Princ Pract 19(6): 440446.

133. Araj $G$ \& Jaber $F$ (2012). In vitro activity of carbapenems against multidrugresistant gram-negative organisms at a tertiary care centre in Lebanon. Clin Microbiol Infect 18: 512-513.

134. Madani N, Rosenthal VD, Dendane T, Abidi K, Zeggwagh AA \& Abouqal R (2009). Health-care associated infections rates, length of stay, and bacterial resistance in an intensive care unit of Morocco: findings of the International Nosocomial Infection Control Consortium (INICC). Int Arch Med 2009 2(1): 29.

135. Abdelmalek R, Kilani B, Kanoun F, Ammari L, Benaissa HT, Goubontini A, Zouiten F \& Chaabane TB (2010). Upper urinary tract infections in adults: about 261 episodes. Tunis Med 88(9): 629-633.

136. Akhtar N (2010). Hospital acquired infections in a medical intensive care unit. J Coll Physicians Surg Pak 20(6): 386-390.

137. Mumtaz S, Ahmad M, Aftab I, Akhtar N, Hassan M \& Hamid A (2008). 
Aerobic vaginal pathogens and their sensitivity pattern. J Ayub Med Coll Abbottabad 20(1): 113-117.

138. Mumtaz S, Ahmad M, Akhtar N \& Hameed A (2008). Extended spectrum beta lactamases in urinary gram negative bacilli and their susceptibility pattern. Pak J Med Res 47(4): 75-78.

139. Khan E, Ejaz M, Zafar A, Jabeen K, Shakoor S, Inayat R \& Hasan R (2010). Increased isolation of ESBL producing Klebsiella pneumoniae with emergence of carbapenem resistant isolates in Pakistan: Report from a tertiary care hospital. J Pak Med Assoc 60(3): 186-190.

140. Al-Tawfiq JA \& Anani AA (2009) Antimicrobial susceptibility pattern of bacterial pathogens causing urinary tract infections in a Saudi Arabian hospital. Chemotherapy 55(2): 127-31

141. Khanfar HS, Bindayna KM, Senok AC \& Botta GA (2009). Extended spectrum beta-lactamases (ESBL) in Escherichia coli and Klebsiella pneumoniae: trends in the hospital and community settings. $J$ Infect Dev Ctries 3(4): 295-299.

142. Saeed NK, Kambal AM \& El-Khizzi NA (2010). Antimicrobial-resistant bacteria in a general intensive care unit in Saudi Arabia. Saudi Med J 31(12): 1341-1349.

143. Mkaouar D, Mahjoubi F, Mezghani S, Znazen A, Ktari S \& Hammami A. (2008). Resistance to third generation cephalosporins in Sfax hospitals, Tunisia 1999-2005). Med Mal Infect 38(6): 293-298.

144. Al-Zarouni M, Senok A, Rashid F, AlJesmi SM \& Panigrahi D (2008). Prevalence and antimicrobial susceptibility pattern of extendedspectrum beta-lactamase-producing Enterobacteriaceae in the United Arab
Emirates. Med Princ Pract 17(1): 3236.

145. Marian T, Plecko V, Vranes J, Mlinaric D, Bedenic B \& Kalenic S (2010). Characterization of ESBL-producing Escherichia coli and Klebsiella pneumoniae strains isolated from urine of nonhospitalized patients in the Zagreb region. Med Glas 7: 46-53.

146. Monjur F, Rizwan F, Asaduzzaman M, Nasrin N, Ghosh NK, Apu AS \& Haque F (2010). Antibiotic sensitivity pattern of causative organisms of neonatal septicemia in an urban hospital of Bangladesh. Indian J Med Sci 64(6): 265-271.

147. Deshpande P, Rodrigues C, Shetty A, Kapadia F, Hedge A \& Soman R (2010). New Delhi metallo-beta lactamase (NDM-1) in Enterobacteriaceae: Treatment options with carbapenems compromised. $J$ Assoc Physicians India 58: 147-9

148. Ahmed SM, Jakribettu RP, Meletath SK \& Vpa S (2013). Lower respiratory tract infections (LTRIs): An insight into the prevalence and the antibiogram of the gram negative, respiratory, bacterial agents. J Clin Diagn Res 7(2): 253-256.

149. Moehario LH, Tjoa E, Kiranasari A, Ningsih I, Rosana Y \& Karuniawati A (2009). Trends in antimicrobial susceptibility of gram-negative bacteria isolated from blood in Jakarta from 2002 to 2008. J Infect Dev Ctries 3(11): 843-848.

150. Chander A \& Shrestha CD (2013). Prevalence of extended spectrum beta lactamase producing Escherichia coli and Klebsiella pneumoniae urinary isolates in a tertiary care hospital in Kathmandu, Nepal. BMC Res Notes 6: 487.

151. Bao L, Peng R, Ren X, Ma R, Li J \& Wang Y (2013). Analysis of some 
common pathogens and their drug resistance to antibiotics. Pak J Med Sci 29(1): 135-139.

152. Khamesipour F \& Tajbakhsh E (2016). Analyzed the genotypic and phenotypic antibiotic resistance patterns of Klebsiella pneumoniae isolated from clinical samples in Iran. Biomedical Research 27 (4): 10171026

153. Woldu MA (2015). Klebsiella pneumoniae and its growing Concern in Healthcare Settings. Clin Exp Pharmacol 6: 199.

154. Abreu A, Marques S, Monteiro NV, Carvalho R \& Gonçalves A (2011). Nosocomial infection and characterization of extended-spectrum ß-lactamases-producing Enterobacteriaceae in Northeast Brazil. Rev Soc Bras Med Trop 44(4): 441446.

155. Orrett FA, Changoor E \& Maharaj N (2010). Pediatric drug prescribing in a regional hospital in Trinidad. J Chin Clin Med 5(3): 157-163.

156. Debby BD, Ganor O, Yasmin M, David L, Nathan K, Ilana T, Dalit S, Smollan G \& Galia R (2012). Epidemiology of carbapenem resistant Klebsiella pneumoniae colonization in an intensive care unit. Eur J Clin Microbiol Infect Dis 31(8): 18111817.

157. Gupta A, Sharma S \& Arora A (2010). Changing trends of in vitro antimicrobial resistance patterns in blood isolates in a tertiary care hospital over a period of 4 years. Indian J Med Sic, 64(11): 485-492.

158. Al-Johan SM, Akhter J, Balkhy H, ElSaed A, Younan M \& Memish Z (2010). Prevalence of antimicrobial resistance among gram-negative isolates in an adult intensive care unit at a tertiary care center in Saudi Arabia. Ann Saudi Med 30(5): 364-369.

159. Sabra S \& Abdel-Fattah M (2012). Epidemiological and microbiological profile of nosocomial infection in Taif hospitals, KSA (2010-2011). World J Med Sci 7(1): 1-9.

160. Bayram Y, Parlak M, Aypak C \& Bayram I (2013). Three-year review of bacteriological profile and antibiogram of burn wound isolates in Van, Turkey. Int J Med Sci 10(1): 19-23.

161. Mandal J, Acharya NS, Buddhapriya D \& Parija SC (2012). Antibiotic resistance pattern among common bacterial uropathogens with a special reference to ciprofloxacin resistant Escherichia coli. Indian J Med Res 136(5): 842-849.

162. Nusrat N \& Ridwan BR (2017). Phylogenetic Analysis of Antibiotic Resistance Genes and Virulence Genes of Klebsiella species in silico. Dhaka Univ. J. Pharm. Sci 16(1): 119-127.

163. Faham K \& Elahe T (2016). Analyzed the genotypic and phenotypic antibiotic resistance patterns of Klebsiella pneumoniae isolated from clinical samples in Iran. Biomed Res 27 (4): 1017-1026. 